\title{
SEDIMENTATION AND LITHOSTRATIGRAPHY OF THE VUOSAARI MULTIPLE TILL SEQUENCE IN HELSINKI, SOUTHERN FINLAND
}

\author{
HEIKKI HIRVAS, PETRI LINTINEN, JUHA PEKKA LUNKKA, \\ BRITA ERIKSSON and TUULIKKI GRÖNLUND
}

HIRVAS, HEIKKI; LINTINEN, PETRI; LUNKKA, JUHA PEKKA; ERIKSSON, BRITA and GRÖNLUND, TUULIKKI 1995. Sedimentation and lithostratigraphy of the Vuosaari multiple till sequence in Helsinki, southern Finland. Bull. Geol. Soc. Finland 67, Part II, 51-64.

A multiple till sequence interbedded with sorted sediments has been investigated at Vuosaari, Helsinki, Finland. The investigation was carried out using standard sedimentological procedures combined with microfossil analysis in order to determine the genesis of the exposed sediments. This evidence is used to correlate lithostratigraphically the sequence with adjacent multiple till sequences in other parts of southern Finland (south of the Salpausselkä zone).

It is concluded that all three till beds at Vuosaari are of basal origin that were laid down by separate ice flow phases. In contrast two rhythmite beds between the tills are thought to have been deposited in open water. The sediments at Vuosaari may have been laid down during the Weichselian glaciation although it is also possible that the lowermost till bed represents Saalian till.

Key words: till, lithostratigraphy, pollen analysis, diatom flora, deposition, correlation, Pleistocene, Vuosaari, Helsinki, Finland,

Heikki Hirvas, Petri Lintinen, Brita Eriksson, Tuulikki Grönlund: Geological survey of Finland, FIN-02150 Espoo, Finland.

Juha Pekka Lunkka: Department of Geology, University of Helsinki, Finland. 


\section{INTRODUCTION}

Finland is situated close to the centre of the area in which the Scandinavian ice-sheet was initiated and spread outwards repeatedly during the Pleistocene. Glacial erosion has greatly affected existing interglacial and glacial deposits. Indeed in most parts of Finland superficial clastic deposits, resting on the Precambrian bedrock, represent solely sediments left behind during the final deglaciation phase of the Weichselian glaciation.

However, there are a number of localities where organic interglacial and interstadial deposits occur, often as erosional remnants (see Hirvas and Nenonen 1987, Hirvas 1991, Donner 1995). Since the interglacial and interstadial organic deposits are not extensively preserved Pleistocene stratigraphy in Finland is mainly based on till stratigraphy.

The longest Pleistocene sequences are best preserved in a wide ice-divide zone in northern Finland where interglacial and interstadial deposits have been used as marker horizons for further correlations of multiple glacigenic clastic sediments (Hirvas and Nenonen 1987, Hirvas 1991). However, the stratigraphy of southern Finland, i.e. south of the Salpausselkä end moraines (Fig. 1), is exclusively based on till stratigraphy since in situ organic sediments that can provide biostratigraphical and/or chronostratigraphical control have not so far been reported from this area.

The lithostratigraphical scheme for southern Finland and its correlation to the sites elsewhere in the country have been proposed by Nenonen and Hirvas (1987) and Bouchard et al. (1990). Lithostratigraphical schemes for southern Finland have also been presented by Rainio and Lahermo (1976, 1984) and Kurkinen et al. (1989).

Hirvas and Nenonen (1987) and Bouchard et al. (1990) have reported two superimposed till units with markedly different physical properties and clast fabric from southern Finland, south of the Salpausselkä end moraines. The uppermost unit here is sand-rich, with clay fraction representing only 1-3\% of the total. This uppermost till is thought to have been deposited during the final deglaciation stage of the Weichselian glaciation. According to till clast fabric and striae measurements, the ice-flow direction during this stage was from $310^{\circ}-320^{\circ}$.

In the Porvoo and Siuntio districts (Fig. 1) two superimposed till beds are separated by a sand unit (Hirvas and Nenonen 1987, Bouchard et al. 1990). The lower till unit is compact and clay-rich (clay content: 10-15\%). According to Rainio and Lahermo (1984) comparable clay-rich till units in southern Finland are occasionally organic-rich and ${ }^{14} \mathrm{C}$ dates obtained from this organic matter have yielded a minimum age of over $45 \mathrm{ka}$. Clast fabric measurements from this till and striae observations on the bedrock beneath indicate that the lower till unit, south of Salpausselkä end moraines, was deposited from $340^{\circ}-360^{\circ}$ (Hirvas and Nenonen 1987, Kurkinen et al. 1989, Bouchard et al., 1990).

Rainio and Lahermo (1976, 1984) suggested that the lower till unit was laid down when ice for the first time overrode underlying Eemian interglacial sediments during the Weichselian glaciation. According to these authors, the high clay and organic content in the lower till was caused by the incorporation of interglacial sediments into this till (Rainio and Lahermo 1976, 1984). Hirvas and Nenonen (1987) considered that the clay-rich lower till could have been deposited either during the Weichselian or during the previous Saalian glaciations.

Based on the observations in southern and western Finland (north of Salpausselkä end moraines and north of the so-called 'Central Finland Ice-Marginal Formation'; Fig. 1) Bouchard et al. (1990) proposed a formal lithostratigraphy for southern Finland. In their lithostratigraphy, the Kela Formation in the Siuntio area comprises two till members separated by a sand member. They suggested that all three members of the Kela Formation were deposited during the Weichselian glaciation. The lower till member representing lodgement till deposited during the first arrival of ice into the Siuntio area from the north (Bouchard 


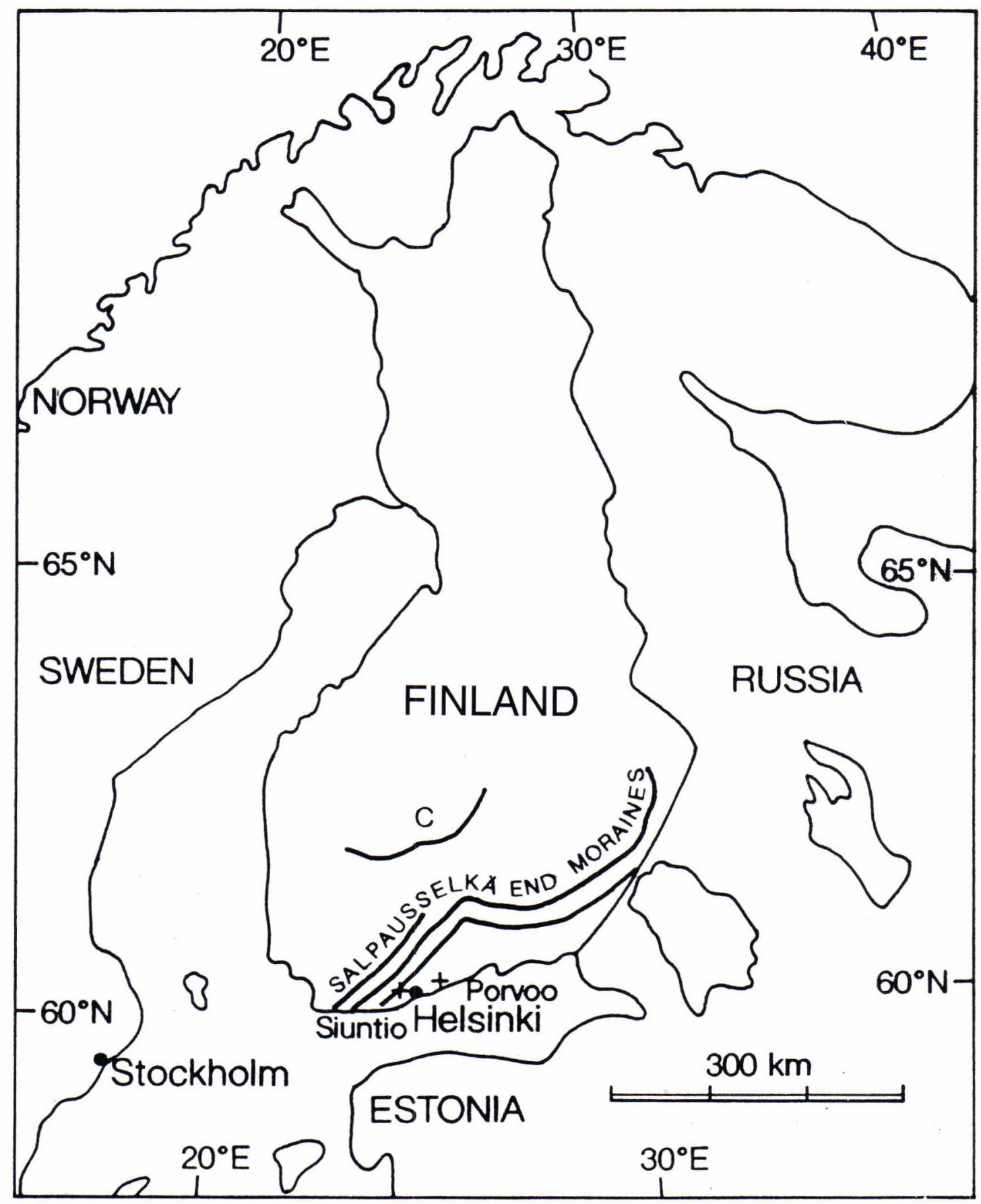

FIG. 1. Location map showing the Vuosaari site in Helsinki and other sites (Siuntio and Porvoo) discussed in the text. The principal end moraine complexes in southern Finland are also shown (C=Central Finland IceMarginal Formation). 
et al. 1990). They also suggested that the upper unit, the Siuntio Till was deposited by basal meltout and the Pikkala Sand member between the two till units represents subglacial outwash sands.

The Vuosaari sequence described here includes three separate till units instead of the two previously reported. The primary aim of this paper is therefore to describe the lithostratigraphy of the Vuosaari sequence and present the most probable depositional environments under which these sediments accumulated. The authors will also discuss the probable correlations of the Vuosaari sequence with those in adjacent areas presented previously.

\section{METHODS}

Conventional logging techniques were used to determine facies changes throughout the Vuosaari pit and to construct a detailed graphic log of the exposure. Textural and structural properties, such as unit thickness, the nature of bedding contacts, dominant grain-size of sorted sediments and bedding structures of each unit were recorded. Clast fabric measurements of the tills were performed by measuring the dip direction of long axes of 50 elongated pebbles. Clasts with dip greater than $30^{\circ}$ were classified as vertical. These methods were used in order to obtain information on the genesis of tills and sorted sediments.

Grain-size analyses from tills were carried out by conventional hydrometer and wet-sieving techniques and the humus content of tills was determined by a calorimetric technique using a Metrohm Spectrocolorimeter E1009. Specific surface area values of the fine fractions $(<0.06$ $\mathrm{mm}$ ) were also measured using a method based on nitrogen sorption (Micrometrics Flow Sorb II 2300) on dry-sieved samples. These methods were used to determine the properties of the tills exposed in the section.

In addition, lithological composition of 6-30 $\mathrm{mm}$ fraction of tills were determined from 300400 clasts to indicate the provenance.

Pollen and diatom analysis were carried out from the rhythmite and till units exposed at Vuosaari. Although microfossil analyses are seldom used for till material this procedure can, in favourable situations, give valuable information on the contemporaneous and reworked flora in sediments (Heinonen 1957, Hirvas and Nenonen 1987, Hirvas 1991). The samples for pollen analysis were treated in the laboratory as described in Eriksson (1993). Whenever possible 200-500 arboreal pollen grains were counted from each sample and the results are shown in percentages of a total pollen sum obtained from each sample.

The preparation of diatom slides followed the conventional preparation method (e.g. Håkansson 1982). The diatom counts are listed in table 1 and shown in a diagram using sub-divisions introduced by Simonsen (1962).

\section{SITE DESCRIPTION}

\section{Lithostratigraphy}

The Vuosaari section is located in East Helsinki on the southern coast of Finland at $15 \mathrm{~m}$ a.s.l. (Fig. 1). The topography of the area is typical of coastal southern Finland where bedrock outcrops, covered partially by till, alternate with low-lying areas which are covered by thick glacial and postglacial clay.

The Vuosaari sequence was discovered during the power station construction conducted by the City of Helsinki. During the excavations a sediment sequence was well exposed in the pit (dimensions $c a .100 \mathrm{~m} \times 100 \mathrm{~m}$ ) and it was possible to trace individual sediment units vertically and laterally throughout the exposure (Fig. 2). The thickest sequence, comprising three separate till units interbedded with stratified sediments, was discovered in the eastern part of the pit lying in a relatively narrow bedrock trough. In the western part of the excavation only two till units interbedded with laminated sediments were preserved overlying the local bedrock.

The sediments at the Vuosaari site rest upon Precambrian, fine-grained, migmatic hornblende 


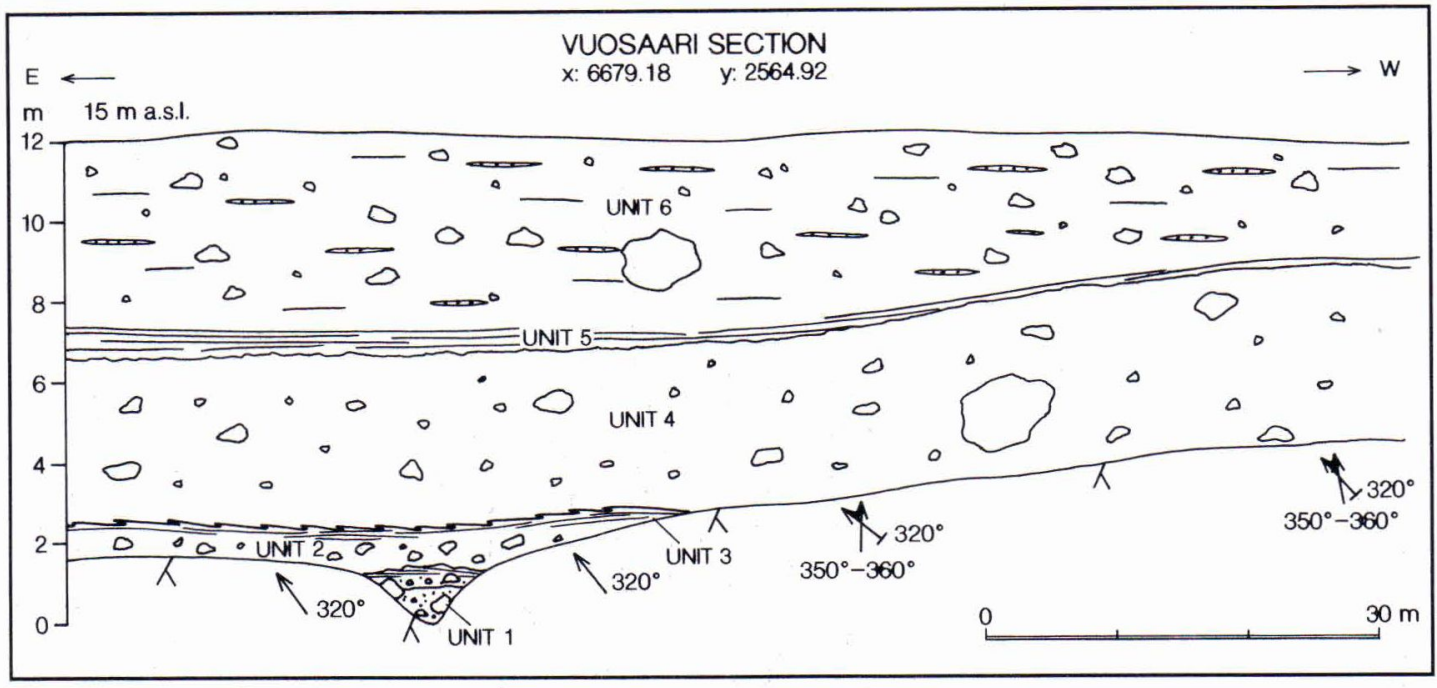

FIG. 2. Sketch of the Vuosaari exposure showing the six sediment units discussed in the text as well as bedrock striae observations obtained from the bedrock outcrops in the pit.

gneiss (Laitala 1991). Glacial striae are well preserved on the surrounding bedrock outcrops and on the bedrock knobs in the pit. The measurements of these striae and cross-striae indicate three separate ice-flow directions; the oldest of which is $310^{\circ}-320^{\circ}$, the intermediate $350^{\circ}-360^{\circ}$ and the youngest flow direction is $320^{\circ}$.

The sequence is shown in Fig. 3 and discussed below starting from the base.

\section{Unit 1 - Sand and gravel facies}

A cobble to boulder rich sand and gravel facies, 0.65-1 m thick, overlies the bedrock. Most of the cobbles and boulders are in contact with the underlying bedrock and are partially overlain by a 0.3 m thick unit of crudely stratified medium sand and fine gravel. This bed is in turn overlain with an erosional lower contact by a $0.2 \mathrm{~m}$ thick, massive fine gravel that includes thin silt strings. The fine gravel unit is conformably capped by $0.15-0.30$ $\mathrm{m}$ thick, laminated fine sand and silt that has been intensively deformed in places.

The lowest sedimentary unit is interpreted as representing two separate flow pulses. The lower of which consists of parallel bedded sand and fine gravel most likely deposited in the upper flow regime. The upper, apparently massive fine gravel and laminated fine sand/silt subunit was laid down during the second flow pulse where laminated fine sand/silt was deposited under waning flow conditions. Both of these subunits, together with the cobble to boulder-sized clasts, could have been deposited as outwash under the ice or possibly just beyond the ice margin.

Unit 2 - Matrix supported massive (partially stratified) sandy till facies

Massive, cobble-rich sandy till, 1.1-1.5 m thick, overlies the laminated silt and sand beneath with an erosional contact. The upper part of the underlying unit 1 has been intensively deformed and some material from sand and silt in unit 1 was incorporated into the lower part of the sandy till. Sandy till contains $27 \%$ of fines $(<0.06 \mathrm{~mm})$ with $2.7 \%$ of clay fraction. The specific surface area of fines is $2.1 \mathrm{~m}^{2} / \mathrm{g}$ and the humus content is $1.1 \%$. Clast fabric measurements carried out from this till show clear preferred clast orientation at $320^{\circ}$. $330^{\circ}$ (Fig. 3) that coincides with the oldest striae 


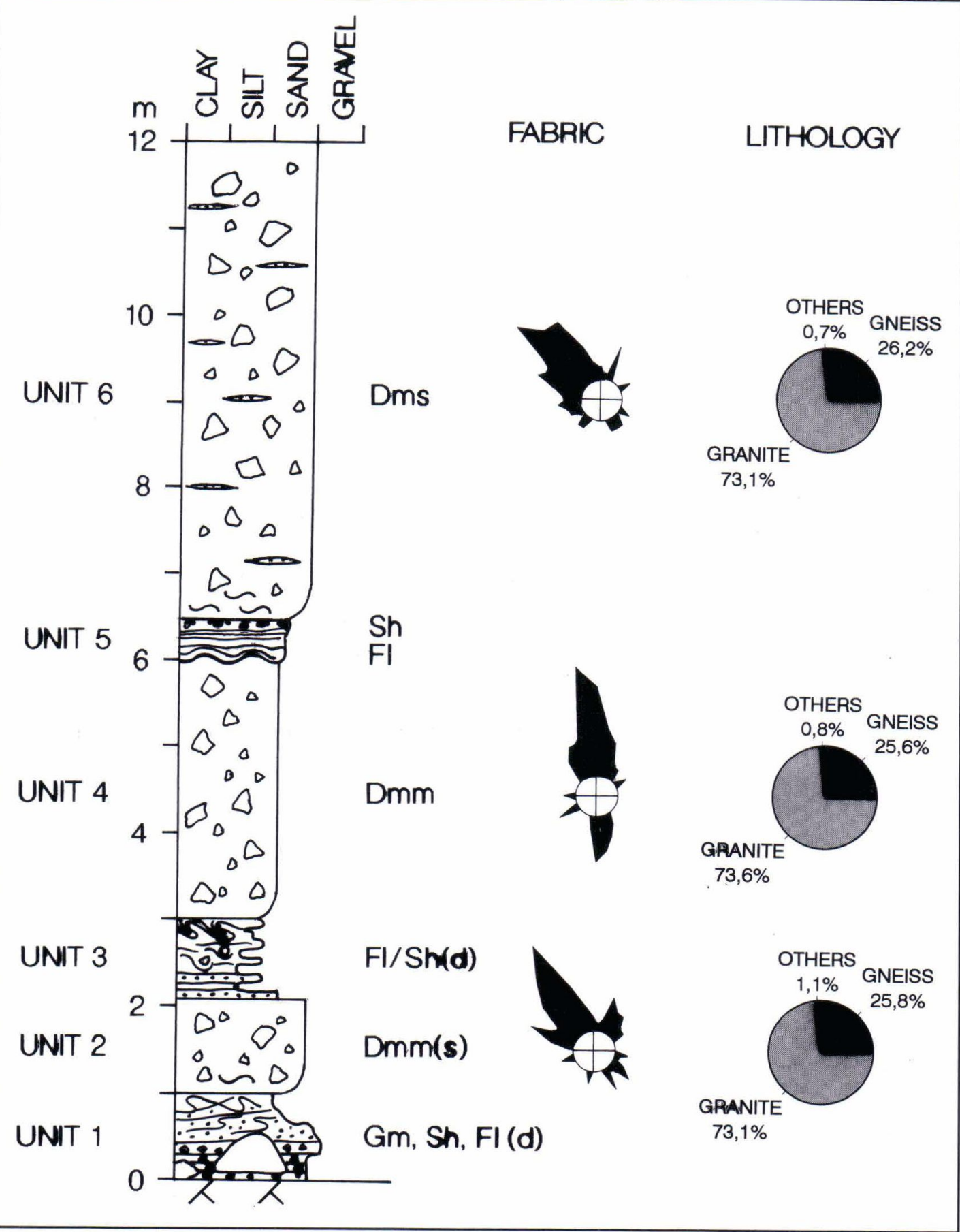

FIG. 3. A lithostratigraphic log from the Vuosaari pit indicating six major sediment units. The till clast fabric and the lithological composition of the tills are also shown. Facies codes: Dmm = Diamicton, matrix supported massive, Dms = Diamicton, matrix supported stratified; Gm = Gravel, crudely bedded; Sh = Sand, horizontally bedded; $F l=$ Silt and clay, laminated; $(s)=$ slightly stratified in places; $(d)=$ deformed. 
orientations $310^{\circ}-320^{\circ}$ found on the bedrock.

The strong, preferred orientation of the clasts in the till, with their dip directions towards the NW, together with the deformation structures at the contact of the laminated silt/sand in the upper part of unit 1 and the overlying till, strongly suggest that the till bed was deposited as a basal till. Moreover, the cobble-rich, sandy till is interpreted as having been deposited by the ice that moved into the area from the northwesterly direction $\left(310^{\circ}-330^{\circ}\right)$.

\section{Unit 3 - Laminated fines and sand facies}

Laminated silt and clay and fine sand unit, 0.3-0.9 $\mathrm{m}$ thick overlies the till beneath with a conformable contact. In these rhythmites, individual laminae are $c a .0 .5-1 \mathrm{~cm}$ thick and the couplets are composed of finer clay or silt layer alternating with coarser fine sand or silt layer. Numerous dropstone-structures caused by pebblesized clasts and blocks of till-like material were also observed in this unit. Partially deformed silt and sand, $10-30 \mathrm{~cm}$ thick, overlies the rhythmites. Deformation structures in this upper part comprise small attenuated, listric folds.

The clear rhythmitic structure of the laminated sediments, together with dropstone structures not caused by glaciotectonic boudinage, most probably indicate sedimentation in a stratified waterbody. It is therefore plausible that the sediments represent remnants of a sediment fill laid down in a glaciolacustrine basin.

\section{Unit 4 - Matrix supported massive fine-grained till facies}

Massive, dark grey, silty till, 3 metres thick on average (maximum thickness $5 \mathrm{~m}$ ), overlies the rhythmite bed with an erosional contact. Till clast fabric shows a clear maximum at $350^{\circ}$ (Fig. 3). The upper surface of till is fluted showing ridgecrests ( $c a .25 \mathrm{~cm}$ high) separated by shallow troughs. The orientation of the crestlines on the fluted surface also show a consistent direction of $350^{\circ}-170^{\circ}$. The silty till contains $48-58 \%$ of fines $(<0.06 \mathrm{~mm})$ and $9.7-12.6 \%$ of the clay fraction. The specific surface area of fines is $5.6-7.3 \mathrm{~m}^{2} / \mathrm{g}$ and the humus content is $1.5 \%$.

The directional evidence (e.g. consistent clast fabric, crestline orientations of the fluted forms, striae orientations on the bedrock surface immediately underlying the unit) obtained from this unit indicate deposition by grounded ice. An erosional lower contact combined with minor deformation structures in the uppermost part of the unit beneath, indicate that this till could have been deposited by lodgement and/or subglacial deformation processes by the ice that entered from the north.

\section{Unit 5 - Laminated fines and sand facies}

Laminated fines rest conformably upon the massive till facies of unit 4 . The laminated unit is between 0.6-0.8 $\mathrm{m}$ thick and passes from silt/clay rhythmites into horizontally bedded sand. In the lower part, silt and silty clay couplets are relatively thick $(8-12 \mathrm{~cm})$ and fill the small basins between the underlying fluted till surface. Higher in the unit individual silt/clay couplets become thinner and occasional fine sand layers, $c a .1 \mathrm{~cm}$ thick, form the coarser laminae of a couplet. Dropstone structures are also common. The rhythmite bed is capped by a $15 \mathrm{~cm}$ thick horizontally bedded medium sand with an erosional contact.

The rhythmite unit is interpreted in a similar way as unit 3 thus representing perhaps a remnant of sediments laid down into a glaciolacustrine basin.

\section{Unit 6 - Matrix supported, stratified till facies}

The topmost 3-5.5 $\mathrm{m}$ of the sequence is composed of stratified sandy till including cobbles and boulders (Fig. 3). The basal contact between this till and the underlying unit is sharp and erosional. The upper part of the till unit is brownish in colour, while the basal part is grey. This colour change reflects the oxidized and unoxidized parts of the till bed. Stratification arises from silt and sand 
strings and lenses that are a few centimetres wide and few tens of centimetres long in section. The stratified sandy till contains $24 \%$ of fines $(<0.06$ $\mathrm{mm}$ ) with $2.4-3.5 \%$ of clay fraction. The specific surface area values of fines are $1.2-2.7 \mathrm{~m}^{2} / \mathrm{g}$ and the humus content is $0.9 \%$.

Clast fabric measurements carried out from this stratified till indicate a clear maximum at $310^{\circ}-320^{\circ}$ that is essentially the same as striae on the surrounding bedrock outcrops.

The stratified till bed is interpreted as a basal till. An erosional lower contact together with a strong and preferred clast fabric that coincides with the youngest bedrock striae in the area strongly support this interpretation.

\section{Pollen analysis}

Seven samples were taken for pollen analyses from the sediment units described above. All the samples analysed were relative poor in pollen (Fig. 4). The lowest number of pollen were obtained in samples from units 1 (the sand and gravel facies at the base of the section) and 6 (the matrix supported, stratified till facies). The pollen contents were greatest in samples from units 3 and 5 (the rhythmite facies).

Almost identical pollen spectra in the basal sand and gravel (unit 1), in two till units (2 and 4) and in the laminated sediments (units 3 and 5), as well as degraded pollen grains together with a low pollen frequency, indicate a redeposited pollen flora. High values of Alnus, Corylus and Quercus and the presence of Ilex and Osmunda reflect that the taxa were initially deposited during interglacial climatic optima.

In the Eemian age sites of western Finland, the most important tree species represented in the pollen spectra are Betula and Alnus ( \pm Picea) together with Corylus (pollen percentages 5-20\%) and deciduous trees (Eriksson 1993). Therefore, it is suggested that the pollen content in the Vuosaari sediments, although redeposited could have been derived from the Eemian deposits.

\section{Diatom analysis}

Diatom analyses were performed from the same sediment samples as those for the pollen analyses. The results are presented in Table 1 and Fig. 5.

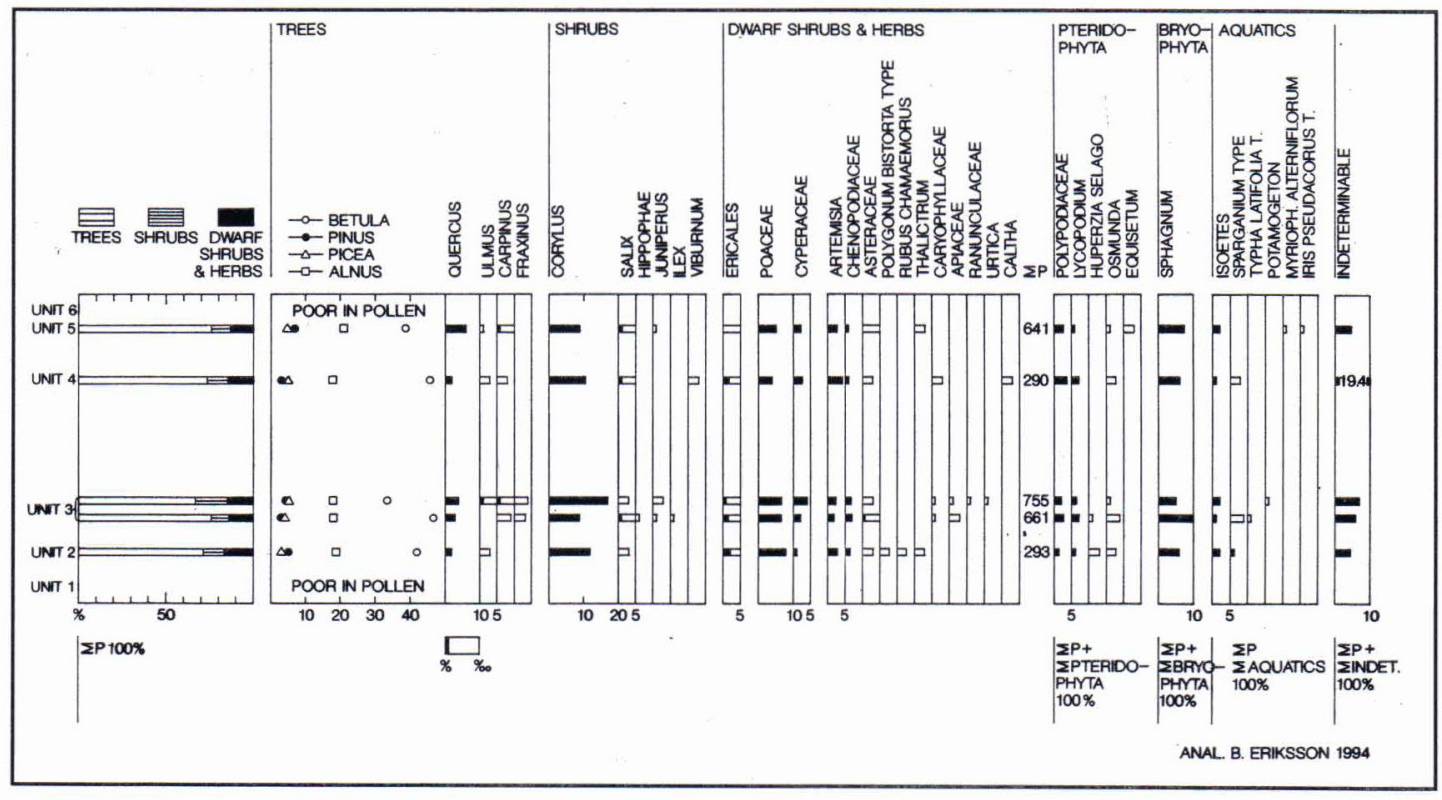

FIG. 4. Pollen content of sediment units 1-6 at Vuosaari. 
Table 1. Diatoms and other algae identified from sediment units 1-6 at Vuosaari.

\section{DIATOMS ANDOTHER ALGAE IDENTIFIEDFROMVUOSAARI}

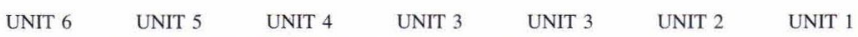

Polyhalobous diatom taxa

Glyphodesmis distans (Gregory) Grunow

Coscinodiscus curvatulus Grunow

Grammatophora arcuata Ehrenberg

Hemiaulus sp.

Navicula lyra Ehrenberg

= Lyrella lyra (Ehrenberg) Karajeva in Round et al. 1990 *

Stephanopyxis turris (Greville) Ralfs

Stephanopyxis spp.

Synedra crystallina (Agardh) Kützing

Trachyneis aspera (Ehrenberg) Cleve

Unknown fragments

Mesohalobous diatom taxa

Campylodiscus echeneis Ehrenberg

Diploneis didyma (Ehrenberg) Cleve

Diploneis smithii (Brébisson) Cleve

Diploneis stroemii Hustedt

Grammatophora oceanica Grunow

Hyalodiscus scoticus (Kützing) Grunow

Nitzschia navicularis (Brébisson) Grunow

Nitzschia scalaris (Ehrenberg) Smith

Paralia sulcata (Ehrenberg) Cleve

Pleurosigma sp.

Rhabdonema arcuatum (Lyngbye) Kützing

Rhabdonema minutum Kützing

Tryblionella punctata W. Smith

Oligohalobous diatom taxa

Aulacoseira ambigua (Grunow) Simonsen

Aulacoseira granulata (Ehrenberg) Simonsen

Aulacoseira islandica (Müller) Simonsen

Aulacoseira italica (Ehrenberg) Simonsen

Aulacoseira lirata (Ehrenberg) Ross

Aulacoseira valida (Grunow) Krammer

Aulacoseira sp.

Cyclotella bodanica Eulenstein

Cyclotella bodanica var. affinis Grunow

Cyclotella comta (Ehrenberg) Kützing

Cyclotella iris Brun
Cymbella ventricosa Kützing
Diploneis finnica (Ehrenberg) Cleve
Ellerbeckia arenaria (Moore) Crawford
Epithemia adnata (Kützing) Rabenhorst
Epithemia argus (Ehrenberg) Kützing
Epithemia turgida (Ehrenberg) Kützing
Eunotia faba (Ehrenberg) Grunow
Eunotia formica Ehrenberg
Fragilaria construens var. binodis (Ehrenberg) Grunow

UNIT $3 \quad$ UNIT 2

UNIT 1

Fragilaria construens var. binodis (Ehrenberg) Grunow

Gomphonema acuminatum var. coronatum (Ehrenberg) Smith

Melosira undulata (Ehrenberg) Kützing

Melosira/Aulacoseira sp.

Pinnularia lata (Brébisson) Smith

Pinnularia spp.

Stauroneis phoenicenteron (Nitzsch) Ehrenberg

Tabellaria flocculosa (Roth) Kützing

Tetracyclus lacustris Ralfs

\section{Other algae}

Actiniscus pentasterias Ehrenberg

Dictyocha fibula Ehrenberg

Distephanus speculum (Ehrenberg) Haeckel

Distephanus speculum var. pentagonus Lemmerman

$\mathrm{P}=$ predominant, more than $10 \%, \mathrm{C}=$ common $1-10 \%,+=$ rare, fewer than $1 \%,-=$ no diatoms noted

* = Round, F.E., Grawford, R.M. \& Mann, D.G. 1990. The diatoms - Biology and morphology of the genera. Cambridge University Press, Cambridge. 747 p.

Anal. T. Grönlund 1994 


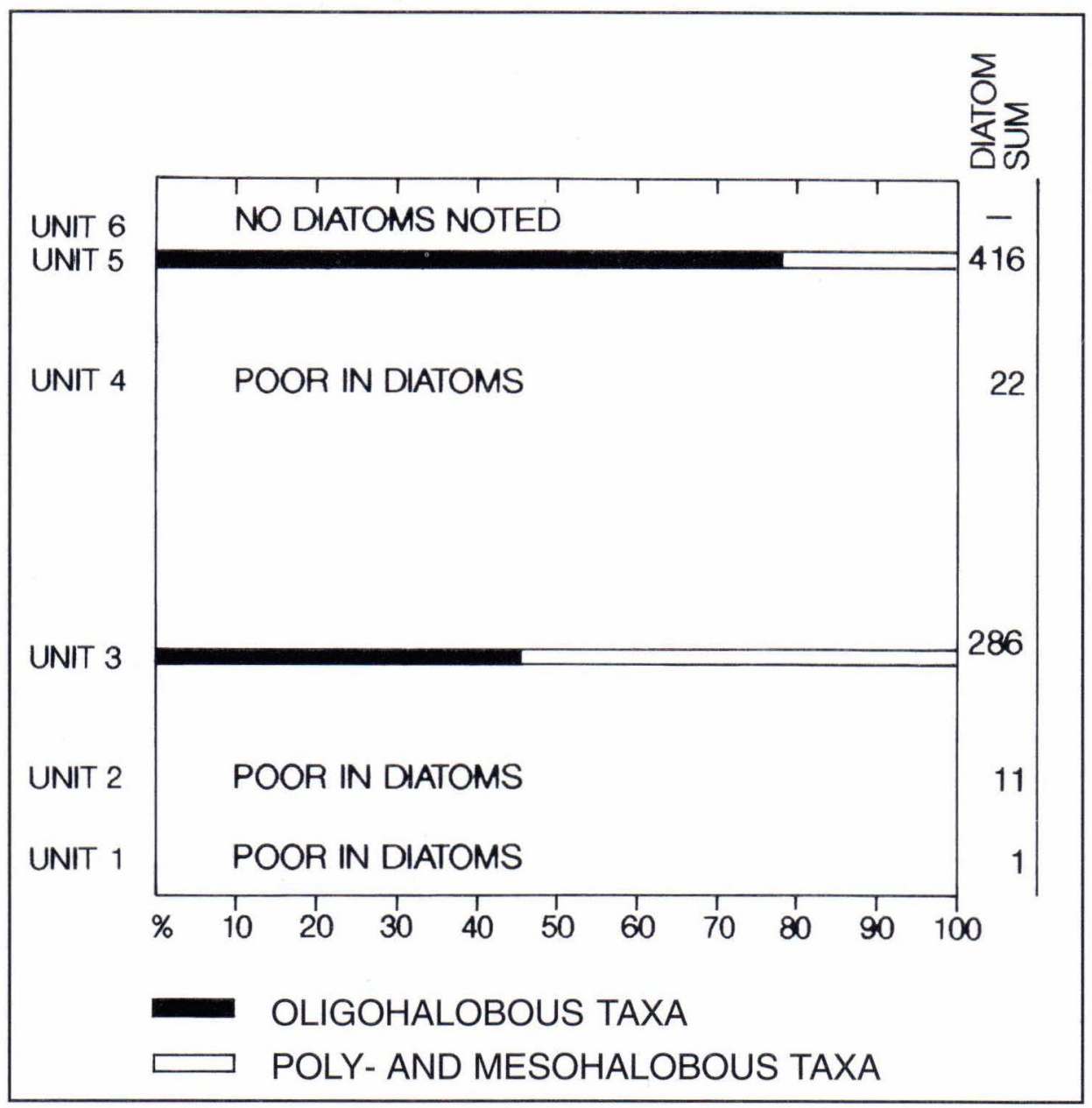

FIG. 5. Oligohalobous versus poly-and mesohalobous diatom taxa from Vuosaari sediments. For detailed taxa see Table 1.

Samples from two lower till units (units 2 and 4) are poor in diatoms and in the uppermost till bed (unit 6) no diatoms were found. Most of the diatoms encountered from two lower tills are freshwater species where Aulacoseira islandica and the species of the_Pinnularia genus dominate. However, Paralia sulcata, Grammatophora oceanica, Trachyneis aspera and Rhabdonema minutum also found in these tills represent saline water forms that were previously reported from Eemian age deposits (cf. Niemelä and Tynni 1979, Grönlund 1991). The samples also contained numerous diatom fragments that could not be identified.

The rhythmite facies (units 3 and 5) contain more diatoms compared to the till units (Fig. 5). A proportion of the diatom frustules recovered from the rhythmites were broken and degraded and therefore could not be determined. In both the rhythmite beds (units 3 and 5) the diatom flora is similar and indicates both freshwater and saline water conditions. The freshwater species Aulacoseira islandica, A. lirata and Pinnularia species together with mesophalobous 
Grammatophora oceanica dominate in these units. However, Diploneis smithii, Hyalodiscus scoticus, Paralia sulcata, Rhabdonema arcuatum and $R$. minitum that indicate saline conditions, are relatively common. Fragments of Hemiaulus species were also identified, this genera is generally well represented in marine Palaeogene diatom flora (cf. Tynni 1982). It is possible that part of the unknown diatom fragments are species common in Tertiary diatom assemblages.

In addition to diatoms some silicoflagellates such as Dictyocha fibula, Distephanus speculum, D. speculum var. pentagonus and dinoflagellate species Actiniscus pentasterias were found in the upper rhythmite bed (unit 5). These marine planktonic algae are also common in the Eemian age Baltic Sea deposits (Niemelä and Tynni 1979, Grönlund 1991).

The diatom floras found in the individual units in the Vuosaari sequence do not differ significantly from each other. This fact, together with the breakage and the scarcity of diatoms, indicates that the diatom flora is mainly redeposited. Both freshwater and marine diatoms were found in the individual samples studied. The frequency of freshwater diatoms is equal to, or greater than the number of marine diatoms. The diatom species indicating saline conditions can also be found in sediments interpreted as being of Eemian age (cf. Niemelä and Tynni 1979, Grönlund 1991)

\section{DISCUSSION}

The Vuosaari section provides the most complete lithostratigraphical sequence for the Pleistocene in southern Finland yet discovered. As stated above, the Vuosaari sequence includes three separate till units that are interpreted as of basal origin. All the directional evidence obtained from cross-striae and clast fabric also indicate that each of these till units were deposited during three separate ice-flow phases. Therefore the three tills at Vuosaari do not represent genetically different till facies (i.e. lodgement, basal melt-out or flow till) that could have been laid down, for example during a single ice-retreat phase (cf. Eyles and Miall 1984).

The sedimentological evidence obtained from the rhythmite beds (units 3 and 5) suggests that these rhythmites were deposited beyond the icemargin in a stratified water-body. It is not possible however to determine the size and the depth of these glaciolacustrine basins. It is plausible that the rhythmite beds preserved represent only the remnants of initially thick basin fills since the tills overlying the waterlaid sediments show erosional contacts. In the rhythmite beds, silt-fine sand/silty clay couplets do not show any current structures but the couplets have sharp basal contacts and also sharp contacts between couplet layers and therefore they are interpreted as results of overflow/interflow events while thicker sand layers are thought to be deposited by underflow mechanisms (Smith and Ashley 1985). These rhythmites were possibly deposited close to the ice margin and do not represent annual varves.

Based on clast fabric, bedrock striae and the physical properties of the tills, the two uppermost till beds (units 4 and 6) at Vuosaari can be lithostratigraphically correlated with the similar till beds in the neighbouring areas described by Rainio and Lahermo (1976, 1984), Hirvas and Nenonen (1987) and Bouchard et al. (1990). However, the lower rhythmite bed (unit 3), the lowermost till (unit 2) and associated sands (unit 1) beneath have not been discovered south of Salpausselkä end moraines.

Unit 6 (the uppermost till) at Vuosaari represents the sandy till facies that occurs widely as a principal unit commonly overlying the crystalline bedrock in the area south of the Salpausselkä end moraines. This till bed was apparently deposited during the final deglaciation stage of the Weichselian ice-sheet as also suggested by Hirvas and Nenonen (1987) and Bouchard et al. (1990).

The clay-rich, massive basal till at Vuosaari can be correlated with a clay-rich till unit occasionally found underlying the more common sandy till 
elsewhere in southern Finland (e.g. Hirvas and Nenonen 1987, Bouchard et al. 1990). Based on till clast fabric and striae observations this till unit was deposited over a wide area when ice overrode region from the north. According to both Rainio and Lahermo (1976, 1984), and Bouchard et al. (1990) the clay-rich, massive till was deposited during the first Weichselian ice-flow stage when the ice covered southern Finland. The high clay and silt content of this till is attributed to intermixing of the Eemian marine deposits during its deposition.

The palaeoenvironmental interpretation of the Vuosaari section presented here differs from the interpretation of the sedimentary sequence in the stratotype section in Espoo proposed by Bouchard et al. (1990). They concluded that the clay-rich till unit (Siuntio Till) in the stratotype section represents lodgement till deposited as the ice entered the Espoo area from the north. Later, during the deglaciation ice covered southern Finland but the depositional mechanisms changed markedly and the so-called Pikkala Sands and Espoo Till were deposited subglacially; the Espoo Till representing basal melt-out till. However, at Vuosaari the rhythmite bed (unit 5) between the upper and the lower till beds (units 4 and 6) was most probably deposited beyond the ice margin into a glaciolacustrine basin, as stated above, indicating an ice-free period between the two flow phases.

As far as the whole sedimentary sequence is concerned, the microfossil assemblages in all the till and rhythmite beds at Vuosaari are fairly similar indicating redeposition of material derived mainly from Eemian interglacial sediments. Although the microfossil assemblages are mainly redeposited, they may partially be indigenous in the rhythmite beds. However, it is not possible to differentiate any of the stratigraphical units at Vuosaari on the basis of their microfossil assemblages. The absence of organic deposits in the Vuosaari section makes it also impossible to answer exactly how many Weichselian ice advances are represented in the Vuosaari sequence.

It seems possible that all the tills at Vuosaari represent Weichselian ice oscillations in a glacial lake in the Baltic basin. However, the striae and stratigraphical observations suggest that these oscillations must have been extensive. On the other hand, one could also argue that the redeposited microfossil assemblage present in the sediments at Vuosaari represents a mixture of material derived from both interglacial and interstadial sediments, deposited before the Eemian interglacial. Therefore, based on the reconstructions of regional extent of the Scandinavian ice-sheet during the Weichselian glaciation (Andersen and Mangerud 1989, Liivrand 1991, Lundqvist 1992), it is possible to link the glacigenic sediments in the Vuosaari section to a broader perspective.

Since it is widely accepted that the initial Weichselian ice-advances did not reach southern Finland including the area discussed here (Sutinen 1984, Donner 1986, 1988, Nenonen 1986, Hirvas and Nenonen 1987, Aalto et al. 1989, Kujansuu et al. 1991, Nenonen, et al. 1991, Lundqvist 1992) the lowermost sand and gravel (unit 1) together with the lower till (unit 2) may represent pre-Weichselian glacigenic sediments possibly deposited during the Saalian. The high clay content in the middle till bed (unit 4) at Vuosaari could have resulted from reworked Eemian marine deposits (see Lundqvist 1973, Rainio and Lahermo 1984, Bouchard et al. 1990). Therefore it is plausible that the middle till bed (unit 4) at Vuosaari is of middle Weichselian age and represents a period when the ice-sheet had already extended beyond southern Finland (e.g. Andersen and Mangerud 1989, Liivrand 1991, Lundqvist 1992) while the uppermost till (unit 6) was left behind during the final retreat of the Scandinavian ice from the study area.

\section{CONCLUSION}

The multiple till sequence exposed at Vuosaari in East Helsinki, southern Finland shows evidence for three ice-flow stages separated by two ice-free periods interpreted here as glaciolacusrine events. 
Although it is not possible to answer exactly how many Weichselian and/or pre-Weicselian ice advances are represented in the Vuosaari section, the middle till (unit 4) at Vuosaari can be correlated by its physical properties and fabric to the lowermost reported till unit that occur in a wide area in southern Finland. Following earlier stratigraphical investigations in Finland, it can be stated that the high clay content of the massive silty till facies (unit 4) may arise from intermixing of fine sediments from the most prominent sediment source, the Eemian age clay deposits.

\section{REFERENCES}

Aalto, M., Donner, J., Hirvas, H., and Niemelä, J. 1989. An interglacial beaver dam deposit at Vimpeli, Ostrobothnia, Finland. Geological Survey of Finland, Bulletin 348, 34 pp.

Andersen, B. G. and Mangerud, J. 1989. An interglacialglacial cycle in Fennoscandia. Quaternary International 3/4, 21-29.

Bouchard, M. A., Gibbard, P. L. and Salonen, V-P. 1990. Lithostratotypes for Weichselian and Pre-Weichselian sediments in southern and western Finland. Bulletin of the Geological Society of Finland 62, 79-95.

Donner, J. 1986. Introduction to the Quaternary of Finland. In: Haavisto-Hyvärinen, M. (ed.); Excursion Guide, Excursion no. 2 - Quaternary geology, southern Finland. Geological Society of Finland, Guide 15, 5-13.

Donner, J. 1988. The Eemian site of Norinkylä compared with other interglacial and interstadial sites in Ostrobothnia, western Finland. Annales Academiae Scientarum Fennicae A III 149, 31 pp.

Donner, J. 1995. The Quaternary History of Scandinavia. World and Regional Geology 7. Cambridge University Press, 200 pp.

Eriksson, B. 1993. The Eemian pollen stratigraphy and vegetational history of Ostrobothnia, Finland. Geological Survey of Finland, Bulletin, 34 pp.

Eyles, N. and Miall, A. D. 1984. Glacial Facies. In Walker, R. G. (ed.): Facies Models. Geoscience Canada, Reprint Series 1, 15-38.

Grönlund, T. 1991. The diatom stratigraphy of the Eemian Baltic Sea on the basis of sediment discoveries in Ostrobothnia, Finland. Geological Survey of Finland, Report of Investigation 102, 26 pp.

Håkansson, $H$. 1984. The recent diatom succession of Lake Havgårdsjön, South Sweden. In Mann, D. G. (ed); Proceedings of the Seventh International Diatom Symposium Philadelphia, August 22-27, 1982.
Koenigstein, 411-429.

Heinonen, L. 1957. Studies on the microfossils in the tills of the North European glaciation. Annales Academiae Scientiarum Fennicae A III, 52 pp.

Hirvas, H. 1991. Pleistocene stratigraphy of Finnish Lapland. Geological Survey of Finland, Bulletin 354, $123 \mathrm{pp}$.

Hirvas $H$. and Nenonen $K$. 1987. The till stratigraphy of Finland. Geological Survey of Finland, Special Paper 3, 49-63.

Kujansuu, R., Saarnisto, M., Räisänen, M-L and Hansel, A. K. 1991. Fossil soil of Kärjenkoski and its correlatives in Ostrobothnia, western Finland. Geological Survey of Finland, Special Paper 12, 119-126.

Kurkinen, I., Niemelä, J. and Tikkanen, J. 1989. Hienoainesmoreenia harjudeltan pohjalla. (Fine-grained till underneathan esker delta). Geologi 41, 47-50.

Laitala, M. 1991. Helsingin kartta-alueen kallioperä. Summary: Pre-Quaternary rocks of the Helsinki mapsheet area. Explanation to the Maps of Pre-Quaternary Rocks, Sheet 2034. Geological Map of Finland 1:100 000. 47 pp.

Liivrand, E. 1991. Biostratigraphy of Pleistocene deposits in Estonia and correlations in Baltic region. Stockholm University, Department of Quaternary Research, Report 19, 114 pp.

Lundquist, J. 1973. Dark bluish boulder-clay: a possible deposit from the first Wurm glaciation. Bulletin of the Geological Institutions of the University of Uppsala 5, 19-20.

Lundquist, J. 1992. Glacial stratigraphy of Sweden. In: Kauranne, K. (ed.); Glacial stratigraphy, engineering geology and earth construction. Geological Survey of Finland, Special Paper 15, 43-59.

Nenonen, K. 1986. Orgaanisen aineksen merkitys moreenistratigrafiassa. Summary: The significance of organic material in till stratigraphy. Geologi 38 (2), 65 76. 
Nenonen, K., Eriksson, B. and Grönlund, T. 1991. The till stratigraphy of Ostrobothnia, western Finland, with reference to new Eemian interglacial sites. In: Andersen, B. G. and Königsson, L. K. (eds); Late Quaternary Stratigraphy in the Nordic Countries $150000-15000$ BP. Striae 34, 65-76.

Niemelä, J. and Tynni, R. 1979. Interglacial and interstadial sediments in the Pohjanmaa region, Finland. Geological Survey of Finland, Bulletin 302, 48 pp.

Rainio, H. and Lahermo, P. 1976. Observations on dark grey basal till in Finland. Bulletin of the Geological Society of Finland 48, 137-152.

Rainio, H. and Lahermo, P. 1984. New aspects on the distribution and origin of so-called dark till. Striae 20, 45-47.
Simonsen, R. 1962. Untersuchungen zur Systematik und Ökologie der Bodendiatomeen der westlichen Ostsee. Internationale Reveue der gesamten Hydrobiologie. Beihefte 1, 144 pp.

Smith, N. D. and Ashley, G. 1985. Proglacial lacustrine environment. In Ashley, G., Shaw, J. \& Smith, N. (eds): Glacial Sedimentary Environments, 135-215. Society of Economic Paleontologists and Mineralogists 16, 137 215.

Sutinen, $R$. 1984. On the Glacial Stratigraphy in Pudasjärvi Area. Striae 20, 91-94.

Tynni, $R$. 1982. The reflection of geological evolution in Tertiary and interglacial diatoms and silicoflagellates in Finnish Lapland. Geological Society of Finland, Bulletin 320, 40 pp. 